\title{
Agualusa sentiu-se estranho, Freyre sentiu-se em casa, e eu, como me senti em Goa?
}

\section{Evandro Luis von Sydow Domingues ${ }^{1}$}

José Eduardo Agualusa, ou o seu narrador, sentiu-se Um Estranho em Goa, nome do seu romance que tem este estado do sul da Índia como cenário. Gilberto Freyre, cerca de 50 anos antes, foi visitar a antiga colônia portuguesa e sentiu-se como se estivera em sua varanda de Apipucos. Eu, que não sou romancista ou sociólogo, mas tãosomente um doutorando que inventou de estudar literatura goesa, ou algo próximo a isso, achei que não ficava bonito escrever tanto sobre Goa e abarrotar uma estante com uma Goiana que, creio, já deva ser a maior do bairro, sem ir lá conhecer aquela realidade. Não que isso fosse necessário, lembraram-me em meu exame de qualificação, mas eu, viajante inveterado, tinha então uma desculpa das boas para conhecer, enfim, a Índia.

Meu primeiro desafio

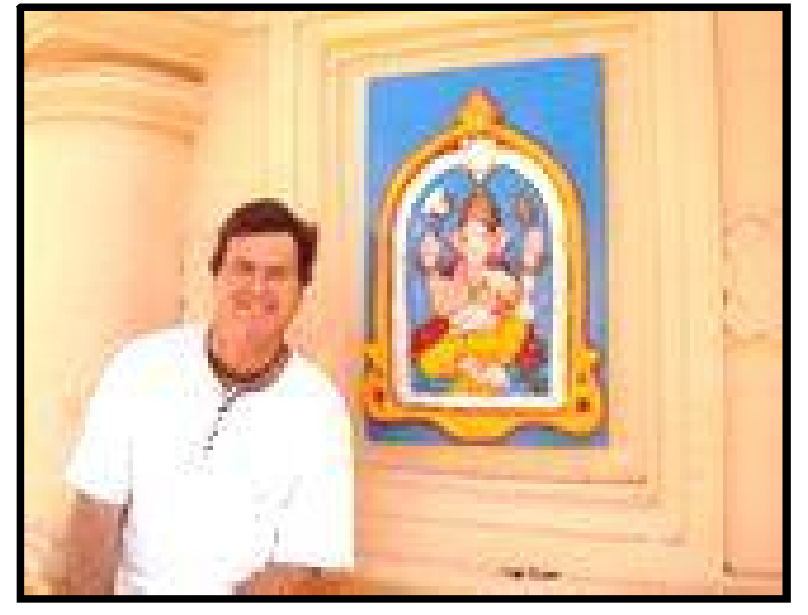
consistiu não em adquirir rúpias ou arquitetar um itinerário menos complexo que o de Gilberto Freyre, que a Goa chegou tendo de passar por Madri, Roma, Egito, Arábia Saudita, Paquistão e Mumbaim, num périplo não muito distinto 
do de Pêro de Covilhã. Outro desafio consistiu em convencer minha mulher a ir comigo, uma vez que, contumazes viajores que somos, já tivéramos uma experiência desagradável na Tunísia. Desagradável para ela, vítima de forte choque cultural, só abrindo a boca para choramingar e só andando pela medina de Tunis quase que arrastada por mim.

Um Lonely Planet aqui, sites com fotos paradisíacas ali, e ela foi, aos poucos, deixando-se persuadir pela idéia, dando seu assentimento categórico: "Está bem. A Goa eu vou, à Índia, não!". Embora eu negue totalmente essa idéia de que Goa não faça parte da Índia, escrevendo mesmo sobre isso em minha tese, concordei com ela triunfante: "A Goa, sim! À Índia, não!”. Vitória.

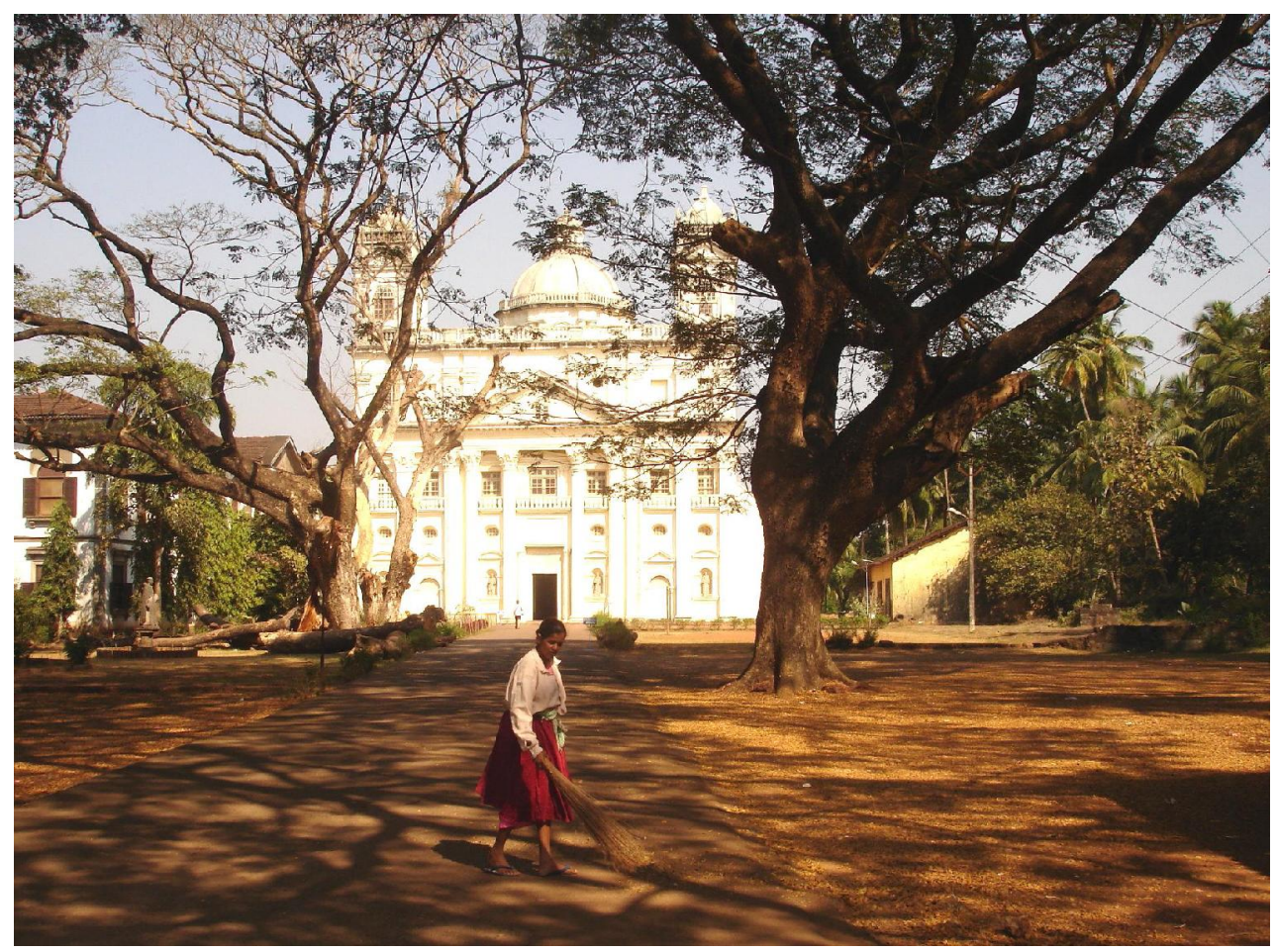

Foto do autor

Circula por aí uma citação atribuída a Proust bastante atraente que, no entanto, à força de ser repetida, presença infalível em antologias de citações, acaba cansando. Vou repeti-la, mais uma vez, aqui: "A verdadeira viagem do descobrimento não consiste em procurar 
novas paisagens, mas em ver com novos olhos". Cito Proust por dois motivos: primeiro, porque Freyre considera sua viagem "proustiana", quando afirma que: "Esta viagem, eu a venho fazendo um tanto proustianamente como quem viesse ao Oriente em busca menos de um tempo que de uma presença” (p. 254). Em segundo porque, se concordamos com a afirmação de Proust acerca do que é uma “verdadeira viagem", a de Freyre não poderia ser mais falsa: ele procura novas paisagens e vê tudo com velhos olhos. Ele sabe de antemão o que vai encontrar. E não se surpreende, como vemos em seu livro de viagens Aventura e Rotina, de 1953, que relata seu périplo por Portugal e pelos então territórios portugueses da Ásia e da África nos anos de 1951 e 1952. Escreve ele: “O que eu principalmente busco nesta viagem quase de estudo: a presença portuguesa."2

Ao buscar essa presença portuguesa, essas "constantes portuguesas de caráter e ação", conforme se lê no subtítulo do seu livro, Freyre estaria, na verdade, procurando o Brasil, as "origens do Brasil em paisagens e populações tocadas (...) pela presença de portugueses" (p. 252). É assim, de olhos bem fechados, que o escritor pernambucano facilmente encontra o que procura.

Sua maneira de ler a realidade dá-se, como era de se esperar, pela comparação. Compara-se tudo, utilizando-se os mais variados recursos lingüísticos para tal - os verbos "lembrar" e "parecer", os adjetivos "semelhante", "parecidíssima", os termos comparativos "menos que", "como se fosse", "tão quanto", "como". Ocorre, então, uma operação lingüística notável: paulatinamente, já não se compara Goa a Portugal ou ao Brasil, mas Goa é Portugal e Brasil. Assim, temos comparações iniciais que, a pouco e pouco, embora estejam presentes em todo o texto, dão lugar à constatação de que a realidade que ora se vê é a realidade que se esperava encontrar, isto é, é a mesma realidade já conhecida, cópia carbono das realidades brasileira e portuguesa. Nos trechos abaixo, temos diversas instâncias comparativas: "Minha impressão de Pangim, a hoje capital de Goa, é menos a de uma cidade exótica para olhos de brasileiro, que de uma pequena e velha capital do 
Norte do Brasil: São Luís do Maranhão, por exemplo."3 e "Recebem-me os hindus de Queula no seu velho pagode com festas que parecem as brasileiras (...)."4

Já no trecho seguinte, suprimem-se os termos da comparação, para se igualar Goa a Portugal e ao Brasil.

$\mathrm{O}$ ar que respiro é o mesmo. As cores que me fazem festa aos olhos, as mesmas cores brasileiras. O mesmo, o olhar das pessoas. O mesmo, o seu sorriso que não tem a exuberância do africano nem as reservas do europeu. Também a mesma fala: o português que ouço na Índia é o português do Brasil, muito mais que o português de Portugal. ${ }^{5}$

Embora o termo "luso-tropicalismo" nasça precisamente nesta viagem, tendo sido utilizado pela primeira vez em uma conferência em Goa, interpretações acerca do colonizador e da colonização portuguesa estão presentes já em Casa-Grande \& Senzala, de 1933. Em 1940, em O Mundo que o Português Criou, o autor generaliza, a partir do caso brasileiro, suas conclusões para todas as colônias e ex-colônias portuguesas. Quando ele enfim conhece Goa, onze anos depois, já sabe de antemão o que encontrará, pois a invenção de um "mundo português" já fora idealizada. O texto trata do nascimento do termo:

Creio ter encontrado nesta expressão - "lusotropical" - a caracterização que me faltava para o complexo de cultura hoje formado pela presença portuguesa em terras tropicais e que tem na identidade de condições tropicais de meio físico e na identidade de formas gerais de cultura - com substâncias de raça e de cultura as mais diversas - suas condições básicas de existência e de expressão. ${ }^{6}$

Chama atenção neste conceito a defesa irrestrita do legado colonial. Séculos de colonização são-nos apresentados na clave da doçura, da cordialidade, da harmonia, da plasticidade: "Tanto quanto lhe permitiu o castismo hindu, o português confraternizou com a gente da terra, misturando-se docemente com ela, adotando vários dos seus costumes, das suas práticas (...).”7 (grifos nossos).

Gilberto Freyre, assim, encontra luso-tropicalismo em Goa e nada mais. Ele vai em busca da Goa Dourada, criação colonial, e a encontra, 
vai em busca da Roma do Oriente e eis a Roma do Oriente a seus pés. Freyre realiza uma prática muito comum entre viajantes a Goa: a vê "de cima”. Ele visita palácios, casarões, a Escola Médica, tem contato com a classe politica dominante. Na missa solene a que assiste, lhe é dado um lugar de honra, entre o presidente do Tribunal de Justiça, o Comandante Militar e o Governador-Geral. Freyre não passeia a pé por Caranzalem, mas faz questão de conhecer a aristocrática aldeia de Loutolim. Em um momento, diz surpreender adolescentes avidamente entregues à leitura de Eça de Queirós e profetiza que a tendência é que continuem a "impregnar-se de cultura latina" (p. 274). Ora, surpreender jovens goeses lendo romances em português em 1951 em Goa é algo tão absurdo que só seria possível se seus anfitriões cuidadosamente houvessem preparado a cena (farsesca) de antemão: tirando das mãos dos rapazes os livros em marata, em concanim e em inglês, e substituindo-os por clássicos lusos.

Podemos então concluir que Freyre só viu o que quis ver, só surpreendeu o que quis surpreender. (Qual a surpresa, então?) E aí, o que acontece? A cultura destes poucos cristãos brâmanes que encontra passa a tipificar a cultura goesa, de fatura luso-tropical. Como bem salientou Robert Newman, os casarões dos brâmanes católicos tornamse "arquitetura goesa", sua comida, a "tipica comida goesa", seus mandós, a "música típica de Goa". Na verdade, a vasta maioria de goeses não é formada por brâmanes, mas por chardós e sudras que são, em sua maioria, hindus. A vasta maioria, isso já em 1951, não utiliza mais o português e nunca chegou a utilizá-lo. Fosse este um trabalho antropológico, poderíamos trazer à baila o conceito de Grande Tradição X Pequena Tradição, de Robert Redfield. Freyre, claro, foi em busca da Grande, para ele a grande e única. 


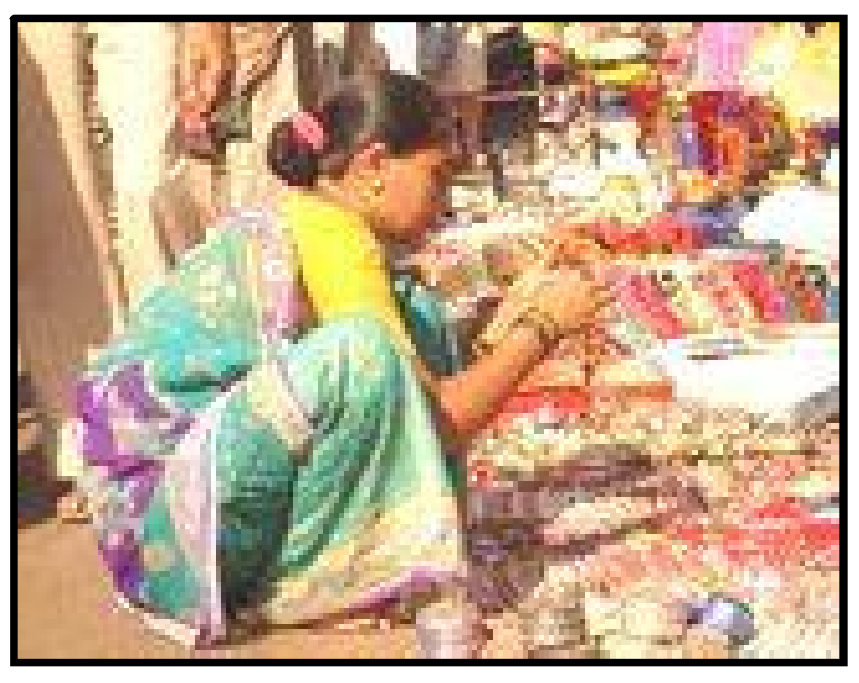

Por muitos anos, e
ainda hoje, é esta a
imagem de Goa que
continua sendo vendida
mundo afora: a Goa
Dourada, a Índia lusa, latina, pedacinho de Europa na Índia, relembrada nostalgicamente em livos como Goa with Love, do ilustrador Mário Miranda, ou CDs como Nostalgic Goa. Não há nas páginas de Freyre sudras ou corumbins. Avistam-se cruzeiros, mas não se avista um único tulsi. Mesmo quando surgem hindus, estes assemelham-se ou "são" lusos: "O Professor Pissurlencar é um scholar e não um puro diletante dos estudos do passado luso-marata. Hindu, é como se fosse um português quando discorre sobre os assuntos de que é mestre."

Só faltou ele dizer que Shantadurga, a Deusa-Mãe venerada em Goa por hindus e católicos, abençoava o domínio português e que até Ganesha, o sempre simpático deus hindu filho de Shiva e Parvati, parecia piscar um olho para Salazar...

Ao contrário de Freyre, o narrador de Um Estranho em Goa não parece ter viajado sabendo de antemão o que encontraria. Ele viaja em busca de um personagem: Plácido Domingo, controvertido capitão português que teria se bandeado para o lado dos guerrilheiros angolanos a fim de atuar como espião. Com a independência de Angola, ele não tem como "voltar" para o seu lado de origem, quedando-se pendurado entre duas identidades. Desaparece. Vira lenda. O narrador, que já o fora buscar em Corumbá, agora está em Goa com a certeza de encontrá-lo. Este, o fio condutor, um tanto frouxo, - ainda que o personagem seja de fato fascinante - da narrativa do romance.

Esta estranha busca gera uma narrativa estranha que causa nos leitores estranhamento. Propositadamente, mistura-se a realidade (o 
escritor Eduardo Agualusa recebeu de fato uma bolsa de criação literária da Fundação Oriente e esteve em Goa) com ficção (o escritor Eduardo Agualusa é um romancista e inventa e escreve sobre o que lhe apraz), o que se poderia configurar em uma poética mestiça, termo utilizado a partir da definição de mestiçagem de Serge Gruzinski. Obra que não é nem relato de viagem, nem romance, ou é os dois, a tratar de um personagem que luta ao lado de portugueses e angolanos, ou contra os dois, em uma Goa que não é nem portuguesa nem indiana. Ou já foi ambas.

Agualusa, em entrevista ao Diário de Notícias por ocasião do lançamento do livro, afirmou ter-se divertido em "enganar o leitor", explorando o lado de logro da literatura que sempre o seduziu. Se em Estação das Chuvas o romance dialogava com a escrita da biografia e com a historiografia, aqui o romance dialoga com o relato de viagem. $\mathrm{Na}$ já citada entrevista, Agualusa afirma que a obra é "ficção pura", embora inclua apontamentos de viagem "integrados nessa ficção". Quando interrogado se o leitor não poderia sentir-se inseguro, o autor afirma que sim, o que corrobora nossa definição de "poética mestiça", cujos procedimentos formais, nas palavras de Gruzinski, "geram no receptor uma constante insegurança” (p. 188).

"Com a verdade me enganas", o narrador recorda-se em passagem o que sua avó costumava dizer-lhe. Aqui não é diferente. Podemos ser facilmente enganados com a verdade, ou com o que aparenta ser verdade, já que é impossível dizer onde esta ficou. "Embora me recorde de ter inventado tudo", diz a passagem. "Naquele caso fiz o contrário", o que nos leva a crer que ele então não inventou, o que é logo confirmado em "Tretas, menti, pura ficção". Apresenta-se a verdade como sendo ficção e a ficção (estamos a ler um romance, não?) como sendo verdade,

Mas é claro que na obra em questão a realidade não atrapalha sua ficção. O que atrapalharia seria ter de dizer onde começa uma e termina outra. Ou tentar pôr termo a este delicioso estranhamento narrativo. 
Assim como Freyre viaja a Goa sem jamais perder de vista o Brasil (bem, até um tanto exageradamente como vimos, já que ele não consegue "ver com os olhos livres"9), o narrador, aqui, tampouco esquece Angola, embora tente ou finja tentar.

Visto que a motivação para o romance, para a viagem e, portanto, para o relato, reside na busca de Plácido Domingo em Goa, poderíamos perguntar ainda por que se busca tal personagem. A resposta parecenos clara: tenta-se ainda entender Angola, juntar as peças deste dificultoso quebra-cabeça que é a história recente deste país africano. Ecos, portanto, de Estação das Chuvas, romance anterior. Mesmo Lídia do Carmo Ferreira, personagem principal de Estação, surge brevemente por aqui, fornecendo algumas pistas acerca do paradeiro de Plácido Domingo.

Quando o narrador enfim é apresentado a Plácido Domingo, este exclama: “- Angola! Também fui angolano", para depois afirmar: "Angola deixou de me interessar. Está tão longe daqui que por vezes chego a duvidar que realmente exista ou tenha existido um país assim. Penso em Angola como você pensa, eu sei lá, no País das Maravilhas..."10

Suas primeiras impressões de Goa assemelham-se sobremaneira às de Freyre: déjà vu. "Ao chegar impressionou-me a amargura das velhas casas, os passeios em ruínas, os muros derrubados. 'Estamos em Luanda', disse a Lili enquanto caminhávamos pelas ruas do centro de Pangim. 'Já conheço isto'."11

O encontro fortuito com a portuguesa Lili irá operar no narrador uma mudança na maneira de se ver a realidade que o circunda. Ela trabalha com técnica de restauro e conservação de livros antigos, e encontra-se em Goa em busca de velhos missais. Sua tese é que "as marcas deixadas num livro pelo seu manuseamento, ao longo dos séculos, fazem parte da história desse livro - eventualmente são essenciais para compreender essa história - e portanto não devem ser eliminadas."12

Fascinado, o narrador pergunta-lhe se então defende que os livros antigos não sejam recuperados, Lili responde que "se devem restaurar 
os livros, mas sem apagar as manchas" (p. 29, grifo meu). E é assim, sem apagar as "manchas" do que vê, sem partir de julgamentos preconcebidos acerca de Goa, que ele transita por cidades, aldeias, mercados, igrejas, diferentes grupos sociais, com olhos de estrangeiro, com olhos de estranho, colhendo as impressões que irão compor sua obra. O encontro com o personagem Plácido Domingo não põe fim à sua viagem. Há que se encontrar ainda com os descendentes, com os freedom fighters, com os padres de Rachol, com os velhos hippies esquecidos em Anjuna. É aqui que a mestiça obra de Agualusa mais funciona como relato de viagem. Não relato turístico, esclareça-se, mas um relato que se revela polifônico ao resgatar as diversas vozes e visões acerca de Goa, que se apresenta aos nossos olhos como uma identificação em curso, assim com a própria identidade do narrador, assim como a identidade do país que procura compreender, tal qual a própria realidade da obra que temos em mãos.

Cheguei a Goa vindo de Paris. Paris-Mumbaim, num vôo já cheio de indianos e, passadas nove horas de espera, Mumbaim-Goa. Chega-se em Mumbaim na parte velha do aeroporto, para quase desespero de minha mulher, mas há logo um shuttle para a parte nova, de mármores e jardins. Neste pequeno percurso de ônibus, minha primeira experiência indiana: a noite abafada, a lua gigantesca, Ganesha e uma suástica em uma porta. Mais do que isso: de dentro do ônibus passamos por muitos e muitos indianos, provavelmente trabalhadores do aeroporto, deitados no chão, multidão deles. Este é um país de bilhão. Lembro-me imediatamente de Carrière: na Índia a solidão é impossivel. 
Depois tudo é muito rápido: as nove horas não pesaram mais que asa de borboleta, já aterrissamos em Goa, já estamos dentro de um táxi. No caminho para o hotel em Dona Paula, perto de Pangim, o inesquecivel: tantas crianças de uniforme, tão concentradas, indo para a escola. Os sáris, os sáris esvoaçantes por toda parte. Os pontos de ônibus, lotados, nas entradas das aldeias. À tarde vou andar, meto-me por Caranzalem sem saber: as corumbinas peixeiras, as casas cristãs, os tulsis. O meu primeiro goês se chama....Caetano Lourenço. Pergunto a uma senhora, em conversa mais de gestos que palavras, se ela é cristã: ela abre a mão para responder, mostrando o terço. Farei como Gilberto Freyre: “parece o Brasil”, "lembra Portugal”? Não, nosso quarto do hotel tem TV de plasma e uma vela com caixa de fósforos. Isto é a Índia. $\mathrm{O}$ dever de casa que me imponho é domar os sentidos, apaziguar um pouco estas algazarras, este soco nos olhos e nos ouvidos. Mas, felizmente, não conseguirei.

Já no segundo

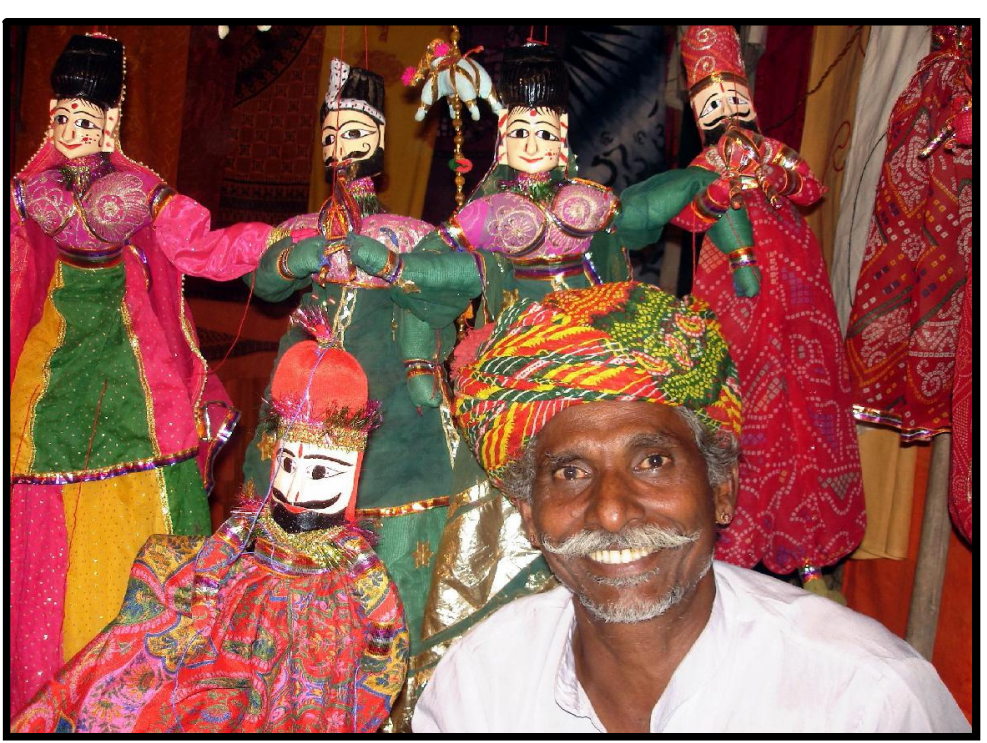
dia tenho contato com duas faces, nem sei se da mesma moeda. Pela manhã, na praia do hotel, puxo conversa com duas senhoras que conversavam em português dentro d’água. Julguei-as portuguesas. Não são, mas goesas que deixaram Goa em 1961, quando Goa deixa de ser colônia. Dizem não ter tido chance: ficar era tornar-se indiano. Foram viver em Portugal e só após 34 anos retornaram a Goa, a passeio. Acham tudo mais sujo agora, mas tentam não imputar a culpa apenas aos indianos, mas também à inexorabilidade do tempo. São portuguesas, dizem, "não temos nada a ver com esta gente". 
À tarde, visito em Pangim Fernando do Rego, com quem já mantinha contato virtual. Mora no coração das Fontainhas, bairro bastião da lusitanidade, mas que, para mim, não tem nada de Bairro Alto, como querem as portuguesas da praia, ou de Mediterrâneo, como querem alguns guias. O problema das comparações. Fernando tem uma posição diametralmente oposta à das portuguesas da Prainha. Nascido também sob domínio português, e falante desta lingua, não só fica após 1961, como abraça a cultura indiana. Todos os seus quatro filhos receberam nomes hindus: Arvind Dilip, Sunil Pravin, Waheeda Teresa e Vivek Subash. Recomenda-nos restaurantes vegetarianos e que não deixemos de visitar templos hindus. E é católico. Tem uma posição conciliadora. O que foi 1961 - invasão ou libertação? - pergunto-lhe. Ora, responde-me, para libertar foi preciso invadir... Talvez esta a dialética goesa. Despede-se de nós com um "namastê", juntando as mãos à frente do peito.

No domingo queremos ir à missa na matriz de Pangim, a Igreja de Nossa Senhora da Conceição, no Altinho. A missa das oito, em concanim, é lotada. Quando esta termina, a igreja esvazia-se quase que totalmente para o culto seguinte, em português. Lá estão as duas senhoras da praia, junto a goeses que resistem. Passados 46 anos do fim da colonização portuguesa, que durou 451 anos, o português não é falado por mais do que $1 \%$ da população. O concanim, no entanto, embora língua oficial, não tem o status de que poderia gozar. Depois de reprimido e desprezado pelos portugueses, hoje é preterido na educação e na imprensa pelo inglês e pelo marata. Goeses, assim, trocam uma lingua "estrangeira" por outra. Muitos dos que combatem o uso do português e desejam vê-lo de todo erradicado de Goa, até da toponímia, fazem uso do inglês diariamente, e não parecem ver nisso um paradoxo.

Mas estávamos na missa e eu desejava conhecer o clã dos Noronha. Óscar de Noronha tem hoje a única editora de Goa que ainda edita livros em português, a Third Millennium. Seu pai foi um dos fundadores da $\operatorname{Voz}$ de Goa, último jornal redigido em português. O contato se deu e Óscar revelou-se um dos amigos desta nossa viagem. 
Durante nossa estada, levou-nos a vetustas igrejonas fora dos guias, mostrou-nos sua editora, falou-nos de seus planos de reeditar clássicos da literatura goesa. Católico como Fernando do Rego, ao contrário deste defende a herança colonial. Acredita no luso-tropicalismo de Gilberto Freyre. Seus filhos se chamam Fernando do Carmo Plinio Noronha, Emmanuel do Carmo José de Noronha, Vera do Carmo Lúcia de Noronha.

Natural que em Goa não passemos despercebidos. Quando perguntam nossa origem, peço que tentem adivinhar. Começam: "Inglaterra", "Rússia", "Alemanha”. Digo que não somos da Europa, o que na maioria das vezes não ajuda muito, pois continuam: "Espanha", "Itália"... Quase ninguém acerta, por mais que falemos de futebol, de língua portuguesa, carnaval, Ronaldinho. Mas, quando revelamos, são todos sorrisos. Em Goa conversa-se muito, principalmente com os vendedores, que não deixam ninguém quieto. Para contrabalançar tantos contatos populares, vamos ter também com a antiga aristocracia goesa, da rica vila de Loutolim. Dona Figueiredo e Mário Miranda, o ilustrador, moram ambos em típicos casarões de arquitetura indoportuguesa. Ela não é descendente, é brâmane católica, palavras suas. Mora hoje em Lisboa, mas vem a Goa passar férias. Tem um dever para com a terra. Sua casa é, na verdade, duas casas. A mais nova, de sua irmã, tem seus trezentos anos. A outra parte ela transformou em Pousada da Dona Figueiredo, onde espero passar alguns dias no futuro, para lavar meus olhos na plantação de arroz que estala de tanto verde. Mário Miranda recebe-nos no imenso salão de sua casa. Ao falar da casa dos Bragança, que visitariamos posteriormente em Chandor, diz ser pena que muitos desses casarões tenham às vezes apenas um morador, velho. Isso lhe lembra o mundo decadente de Faulkner, Tennessee Williams.... E completa: "Eu gosto da decadência...”. 
Também eu. E do segredo do segredo. Não satisfeito em estar em Goa, destino não muito comum para brasileiros, resolvo ir a Divar, uma ilha a que se chega a partir de Ribandar. Piedade é um dos bairros desta ilha. Subi a colina que leva até a igreja. Não dá para entender como uma igreja tão monstruosamente grande, como algumas de Olinda, foi construída por ali. Será que Piedade teve seus dias de Velha Goa, a antiga capital que, devido a seus dias de glória, foi chamada de Roma do Oriente? O local pareceu-me bastante isolado. No caminho da subida, um templo novinho dedicado a Ganesha, na verdade a reconstrução de um anterior provavelmente destruído por muçulmanos no final do século XV. Do templo vê-se a igreja e vice-versa. Como convivem ambos em aparente harmonia, posso tomar essa colina, que abriga Ganesha e Nossa Senhora da Compaixão, como símbolo de Goa?

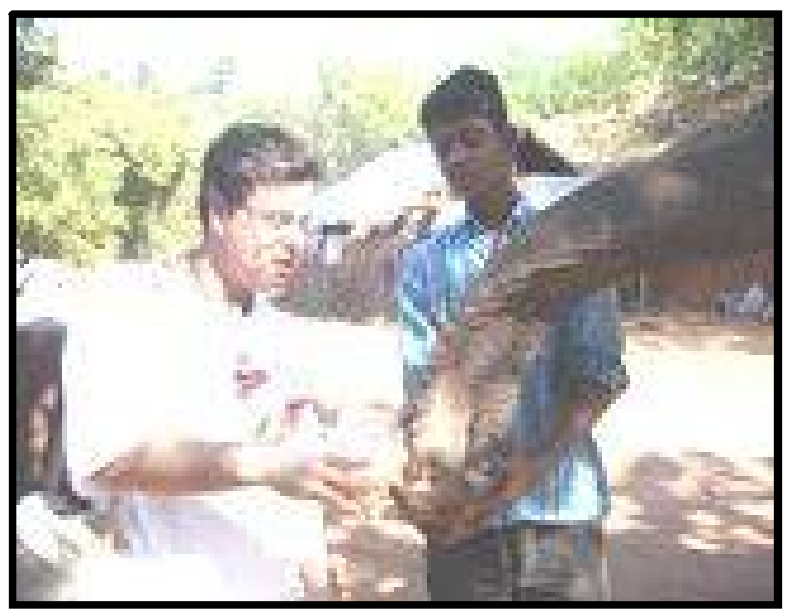

Talvez sim. Mas sem esquecer de que o templo é vivo, o jovem sacerdote lá estava, sorridente, ao passo que a igreja parecia um imenso sepulcro.

Consigo entrar na igreja, após uma daquelas conversas de gestos, em que repito "Dev borém korum", "Dev borém korum" ("Muito obrigado"), para sorrisos deleite de meus interlocutores. Anjos-sereias suportam os púlpitos. Como se não bastasse o estranhamento em si - anjos-sereias, sim, provo-o, tenho fotos - não posso deixar de ver aqui outra representação emblemática de Goa, visto que são duas figuras híbridas. Como Goa.

No Museu Arqueológico de Velha Goa conheço a famosa estátua de Camões, que ficava no centro da antiga capital. No seu pedestal lêse: "Camões / O gênio da pátria / pelo mundo / em / pedaços repartida / Oferta de Portugal da Índia / À Índia de Portugal / 1960”. Mil novecentos e sessenta! Um ano antes do fim do dominio português e ainda se fala firmemente em "Índia de Portugal, Portugal da Índia". Ao 
contrário de outras metrópoles européias, que sempre distinguiram claramente metrópole de colônia, como o caso de Inglaterra e Índia, para Portugal, ao menos ideologicamente, Goa não era "colônia", mas era Portugal, a tal da pátria "em pedaços repartida".

Pois bem, depois que Goa é incorporada à União Indiana, surge o dilema: que farei com esta estátua? Ela continua no centro de Velha Goa até 1983 quando decidem que é uma lembrança inaceitável da época colonial e, portanto, não pode continuar onde está. Alguns radicais propuseram explodi-la, quando autoridades houveram por bem removê-la para o museu. Penso esta estátua como uma metonímia do legado português em Goa. "Que faremos com esta estátua?", perguntaram-se goeses desejosos de construir uma nova realidade que, por causa da colonização, sempre esteve de costas voltadas para a Índia. Que faremos com esta lingua, com estes casarões, com estas igrejas e capelas que coalham a paisagem, com este chutney de bacalhau? Uma estátua até se explode, mas e o resto? E a Igreja de Bom Jesus, a do corpo de São Francisco Xavier, visitada por hindus descalços?

Não fui a Goa em busca de permanências de essências de uma cultura luso-tropical, porque isso não existe. São Francisco Xavier é um santo da Índia, como o catolicismo é já, hoje, uma religião, senão indiana, da Índia, uma delas, principalmente se levarmos em consideração as práticas religiosas banhadas de mestiçagem. O mesmo se dá com a língua portuguesa. Neste país que tudo recicla ("Na Índia não se desperdiça nada, nem impérios caídos"13), a "Índia Latina" é cheia de indianidades, já é abarrotada de "Indian style", de que o trânsito é ótimo exemplo. Na motocicleta viaja a família: marido e mulher, entre eles três filhos. Os carros, os ônibus, os rickshaws, as vacas, os pedestres, as lambretas, os búfalos. Faltam calçadas e sinais de trânsito. Uma rua estreita é de mão dupla. Veículos cruzam-se e milimetros os separam. Tiram tinta do retrovisor a todo instante. Please horn. Blow OK Horn. São milhares e milhares de deuses. Ainda que um se distraia, sempre haverá um outro atento. 
Já próximo de encerrar a viagem, volto à loja de castanhas de caju próxima ao hotel. Depois de alguma conversa, o vendedor me pergunta se sou indiano. Não posso crer em sua pergunta. Ele, que é de Gujarat, só pode estar troçando deste brasileiro que, apesar de muito sol goês, é assaz branquinho, denunciando sangues de Domingues e von Sydows que o geraram. Mas ele falava sério. Frederick Noronha, jornalista que também tivemos o prazer de visitar em sua casa em Saligão, já comentara sobre isso: passado um ano na Índia, eu me tornaria indiano. Para este simpático vendedor de castanhas, bastou um punhado de dias...

Em nossos últimos dias em Goa, deixamos que as recepcionistas do hotel, em meio a gostosas risadas, pintassem em nossas testas o rubro cucume, tão caracteristicamente indiano, que exibimos, felizes, triunfais, por todo o hotel, por toda Pangim. Se um outro vendedor de caju me aparecesse e fizesse a mesma pergunta: "Você é indiano?", hoje responderia: "Um pouco". E é provável que eu termine esta tese mais indiano do que quando a comecei. É possivel mesmo que eu esteja um pouco mais goês agora do que estava quando comecei a escrever este diário: "o privilégio de se pertencer a vários mundos numa só vida". ${ }^{14}$ 


\section{Referências Bibliográficas}

AGUALUSA, José Eduardo. Um Estranho em Goa. Rio de Janeiro: Gryphus, 2001.

FREYRE, Gilberto. Aventura e Rotina. Sugestões de uma viagem à procura das constantes portuguesas de caráter e ação. $2^{\text {a }}$ ed. Rio de Janeiro: José Olympio, 1980.

GOMES, Paulo Varela et alii. Himalayan Express. Mantra, Memória e Viagem na Índia. Coimbra: Almedina, s.d.

GRUZINSKI, Serge. O Pensamento Mestiço. São Paulo: Companhia das Letras, 2001.

HUTCHeON, Linda. Poética do Pós-Modernismo. Rio de Janeiro: Imago, 1997.

NEWMAN, Robert S. Of Umbrellas, Goddesses \& Dreams. Mapusa: Other India Press, 2001.

REDFIELD, Robert. Society and Culture. Chicago: University of Chicago Press, 1956.

SANTOS, Boaventura de Sousa. Pela Mão de Alice. O Social e o Político na Pós-modernidade. 2a ed. São Paulo: Cortez, 1996.

\footnotetext{
1 Doutorando do Programa de Pós-Graduação em Literatura Comparada da UFF (Universidade Federal Fluminense - RJ). Pesquisa: "F(r)icções goesas". evandrodomingues@oi.com.br

2 Freyre, 1980, p. 254.

3 Freyre, 1980, p. 255.

4 Freyre, 1980, p. 277.

5 Freyre, 1980, p. 256.

${ }^{6}$ Freyre, 1980, p. 259.

7 Freyre, 1980, p. 266.

8 Freyre, 1980, p. 261.

9 No feliz verso de Oswald de Andrade.

10 Agualusa, 2001, p. 46.
} 
11 Agualusa, 2001, p. 50.

12 Agualusa, 2001, p. 28.

13 Gomes, s.d., p. 29.

14 Gruzinski, 2001, p. 320. 